\title{
Comparison of polymerase chain reaction technique with other methods for detection of Mycobacterium leprae in tissues of wild nine-banded armadillos
}

\author{
C K JOB, V DRAIN, D L WILLIAMS, T P GILLIS, \\ R W TRUMAN, R M SANCHEZ, A T DEMING \& \\ R C HASTINGS \\ Laboratory Research Branch, Gillis W. Long Hansen's Disease \\ Center, 5445 Point Clair Road, Carville, Louisiana, 70721, USA
}

Accepted for publication 14 June 1991

\begin{abstract}
Summary Thirty, nine-banded armadillos weighing between 3 and 5 kilograms trapped from an area endemic for armadillo leprosy were collected at random; killed, autopsied and examined histopathologically. Also, one of the right inguinal lymph nodes was removed under sterile precautions and examined using PCR, direct smear examination, mouse footpad study, culture in laboratory media and histopathology with a view to detecting Mycobacterium leprae. Blood was collected at death and tested for IgM antibodies to PGL-1.

According to the PCR study of the inguinal lymph nodes 16 of 30 armadillos (53.3\%) had evidence of $\boldsymbol{M}$. leprae. Significant levels of IgM antibodies to PGL-1 and identifiable lepromatous granuloma in inguinal lymph nodes were found in 2 animals $(6.7 \%)$ with advanced disseminated disease. The prevalence of generalized leprosy according to autopsy study was $13.3 \%$ and according to histopathological examination of ear tissue $3 \cdot 3 \%$. The presence of $M$. leprae in the tissues evoked no special tissue reaction in the early stages. The pattern of spread of the disease in 2 animals closely resembled that found in experimental animals infected intracutaneously. Initiation of infection by inoculation of $M$. leprae through thorn pricks remains a distinct possibility.
\end{abstract}

\section{Introduction}

Leprosy in the wild nine-banded armadillos of Louisiana was first reported in $1975 .^{1}$ The rate of infection as determined by histopathological examination at autopsy in animals caught from various regions in Louisiana varied from $4 \%$ to $29 \cdot 6 \%{ }^{2}$ Smith el al. confirmed the occurrence of naturally-acquired leprosy in wild armadillos and according to their studies the prevalence rate in different areas in the Texas Gulf Coast and in Louisiana varied from $1 \%$ to $15 \cdot 4 \% .^{3-5}$ Since the discovery of phenolic glycolipid-1 (PGL-1), a substance specific to M. leprae, ${ }^{6}$ the presence of IgM antibodies to PGL-1 (AbPGL-1) in leprosy patients and their contacts has been reported. ${ }^{7,8}$ The presence of 
AbPGL-1 in wild armadillos was investigated and it was found that up to $20 \%$ of Louisiana armadillos were positive for these antibodies. ${ }^{9}$

Recently it was reported that using a specific polymerase chain reaction (PCR), based on DNA sequences present in the $18 \mathrm{kDA}$ protein gene, as few as $100 \mathrm{M}$. leprae could be detected in tissues. ${ }^{10}$ This method is a valuable addition to other methods available to study the prevalence of infection, mode of transmission, and the pathogenesis of leprosy in armadillos in nature and perhaps helps us to further clarify our understanding of human leprosy.

\section{Materials and methods}

Nine-banded armadillos trapped from different parts of Iberville Parish, Louisiana are regularly used for experimental studies in the laboratory. Invariably, on routine screening some among them are found to have naturally occurring leprosy. We used 30 consecutive animals weighing between 3 and $5 \mathrm{~kg}$ collected from the area for this study.

The armadillos were killed under anesthesia by exsanguination and a thorough autopsy was done within a week of their being received in the laboratory. Plasma was separated from blood obtained at autopsy for antibody studies.

\section{AUTOPSY STUDIES}

In the earlier autopsy study of experimentally-infected lepromatous armadillos it was found that the inguinal and axillary lymph nodes were more frequently colonized by $M$. leprae than any other organs studied. ${ }^{11}$ Therefore, it was planned to use the right inguinal nodes to investigate in detail the presence of acid-fast organisms (AFB) in all 30 animals using several different techniques. Ordinarily 2 to 3 enlarged lymph nodes were found in the inguinal region. They were removed under strict sterile conditions. The skin over the inguinal region was shaved and cleansed twice for 5 min using ACUdyne (containing a mixture of iodine compounds and detergents) skin cleanser (ACME United Corporation) dried with sterile gauze and twice more cleansed with $70 \%$ alcohol and dried. The lymph nodes were dissected out using another set of sterile instruments. One of the lymph nodes excised was divided into 3 portions; one was used for PCR studies, another for histology and the third for microbiological studies. Only histopathological studies were done on the remaining nodes. During autopsy, tissue pieces were removed from liver, spleen, left inguinal lymph nodes, left and right axillary and mesenteric lymph nodes, left and right sciatic nerves, heart, lungs, adrenals, kidneys, testes or ovaries and uterus, nose, ears and tongue. All the 4 footpads were dissected out and were divided longitudinally into several pieces so that the footpads in their entirety could be examined. Tissues were fixed in $10 \%$ buffered formalin and were processed for paraffin sections. Five micron sections were cut and stained with hematoxylin-eosin and a modified Fite stain for AFB. The bacterial load was assessed according to Ridley's scale from 0 to $6+.{ }^{12}$

\section{PCR STUDIES}

Lymph nodes $(200 \mathrm{mg}$ ) were prepared by mincing with scissors, followed by homogenization in $2 \mathrm{ml}$ of Hanks balanced salt solution using a Mickle homogenizer (Mickle 
Laboratory Engineering, Surrey, UK) with 25, 3-mm diameter sterile glass beads for $1 \mathrm{~min}$ at $25^{\circ} \mathrm{C}$. Tissue debris was allowed to settle at $1 \mathrm{~g}$ for $5 \mathrm{~min}$ and the supernate was decanted and saved. One hundred microlitres of digestion buffer containing $250 \mu \mathrm{g}$ proteinase $\mathrm{K}(10)$ were added to $0.4 \mathrm{ml}$ of lymph node homogenate and the mixture was held at $60^{\circ} \mathrm{C}$ for $30 \mathrm{~min}$. Inactivation of proteinase $\mathrm{K}$ was accomplished by shifting the temperature of the mixture to $94^{\circ} \mathrm{C}$ for $8 \mathrm{~min}$. The homogenates were cooled to room temperature and $500 \mu \mathrm{g}$ of lysozyme in $50 \mu \mathrm{l}$ (Sigma Chemical Company, St Louis, MO) were added and the samples were held at $37^{\circ} \mathrm{C}$ for $30 \mathrm{~min}$. Proteinase $\mathrm{K}(250 \mu \mathrm{g})$ was added again and samples were held at $60^{\circ} \mathrm{C}$ for $30 \mathrm{~min}$. The enzyme-digested homogenates were extracted with an equal volume of phenol/chloroform isoamyl alcohol $(1: 1)$ and the resultant aqueous phase was extracted with an equal volume of chloroform/ isoamyl alcohol $(1: 1)$. The DNA in the aqueous phase was precipitated with 2 volumes of ethanol at $-20^{\circ} \mathrm{C}$ for $2 \mathrm{hr}$ and the precipitate was resuspended in $30 \mu \mathrm{l}$ of sterile distilled water. Two mock buffer samples were processed identically and served as negative controls to monitor possible contamination of samples with $M$. leprae DNA during processing. We have reported earlier that uninfected armadillo tissue homogenates and purified armadillo DNA test negative in PCR. ${ }^{10}$

Ten microlitres of the resuspended material was added to the PCR reaction tube containing oligonucleotide primers which have been shown to amplify an M. lepraespecific 360 base pair (bp) DNA fragment. ${ }^{10}$ Thermocycling parameters and buffer conditions for optimal production of this fragment have been described. ${ }^{10}$ Detection of the 360 bp PCR product was by gel electrophoresis and DNA hybridization analysis using $\mathrm{a}^{32}$ p-labelled $212 \mathrm{bp}$ probe specific for the $360 \mathrm{bp}$ PCR product.

\section{MICROBIOLOGICAL STUDIES}

A piece of the lymph node weighing approximately $0 \cdot 2 \mathrm{~g}$ was ground up in a sterile mortar and pestle. To the homogenized tissue $2 \mathrm{ml}$ of Hanks balanced salt solution was added and mixed. Approximately $1 \mathrm{ml}$ of this homogenate was used to inoculate 3 LowensteinJensen slants (LJ) and 3 Middlebrook's 7H11 agar plates. One of each was incubated at $25^{\circ} \mathrm{C}, 33^{\circ} \mathrm{C}$ and $37^{\circ} \mathrm{C}$ for 8 weeks. They were checked for growth at $24 \mathrm{hr}, 48 \mathrm{hr}$, and every week for 8 weeks, and the organisms grown were subjected to standard identification procedures. ${ }^{13}$ The remainder of the homogenate was put into a Mickle cup with glass beads, homogenized for $2 \mathrm{~min}$, and was allowed to settle for $5 \mathrm{~min}$. The supernatant fluid was aspirated, smears were made and were stained for AFB. The AFB in the supernatant were counted according to the method described by Shepard. ${ }^{14}$ The suspension was then diluted so as to contain $5000 \mathrm{AFB}$ in $0.03 \mathrm{ml}$. Both hind footpads of $5 \mathrm{BALB} / \mathrm{c}$ mice were inoculated with $5000 \mathrm{AFB}$ in $0.03 \mathrm{ml}$ of the suspension. If no organisms were seen in the smear $0.03 \mathrm{ml}$ of the supernate from the homogenate was used for inoculating each hind footpad of 5 mice. Harvesting of the footpads for AFB was carried out at 6 and 9 months and the number of bacilli obtained at the earliest period of positivity are given in Table 1 .

\section{IGM ANTIBODIES TO PHENOLIC GLYCOLIPID-1}

Plasma samples were tested in an ELISA for IgM antibodies to the phenolic glycolipid-1 (PGL-1) antigen of $M$. leprae using the method described previously. ${ }^{9}$ The PGL-1 antigen was prepared by Dr Patrick Brennan (Colorado State University, Fort Collins) and 
provided through contract with the National Institutes of Allergy and Infectious Diseases (Dr Darrell Gwinn, Leprosy Project Officer). The resulting ELISA absorbances were judged for positive and negative reaction using the earlier definitions. ${ }^{9}$ Values from 0 to $580(\mathrm{OD} \times 10)^{3}$ were considered negative, and from 580 to 720 were equivocal and 721 and above were positive. Specificity of the reactions were confirmed by adsorbing presumed positive plasmas with whole $M$. leprae and other mycobacterial species. The ELISA absorbency of a true positive was significantly reduced by absorption with $M$. leprae but not altered by absorption with the other mycobacterial species. ${ }^{9}$

\section{Results}

The inguinal lymph nodes were enlarged on both sides in all animals as compared to animals housed in captivity. There were 2 to 3 of them on each side and together they weighed 1 to $2 \mathrm{~g}$. One lymph node from the right side removed under strict sterile

Table 1. Armadillos (21) with AFB in the right inguinal node in one or more tests and IgM antibody values to PGL-1

\begin{tabular}{|c|c|c|c|c|c|c|}
\hline $\begin{array}{c}\text { Serial } \\
\text { No. }\end{array}$ & PCR & $\begin{array}{l}\text { Smear from homogenate } \\
\text { and AFB count per gramme } \\
\text { of tissue }\end{array}$ & $\begin{array}{l}\text { Growth of AFB in } \\
\text { footpads. } \\
\text { Count per footpad }\end{array}$ & $\begin{array}{l}\text { Culture of AFB in } \\
7 \mathrm{H} 11 \mathrm{LJ} \text { medium at } \\
25^{\circ} \mathrm{C}, 33^{\circ} \mathrm{C} \& 37^{\circ} \mathrm{C}\end{array}$ & $\begin{array}{l}\text { Histopath. } \\
\text { exam. }\end{array}$ & $\begin{array}{c}\text { IgM antibodies to } \\
\text { PGL-1 ELISA absorbance } \\
\text { OD } \times 10^{3}\end{array}$ \\
\hline 1 & - & $4.58 \times 10^{5}$ & Not done & - & $1+$ & 447 \\
\hline 3 & + & $5.24 \times 10^{5}$ & $6.60 \times 10^{5 *}$ & - & $1+$ & $\begin{array}{c}620 \\
\text { (equivocal) }\end{array}$ \\
\hline 5 & + & - & - & - & - & 363 \\
\hline 6 & + & - & Failed & - & $1+$ & 412 \\
\hline 10 & + & - & $3.60 \times 10^{4} \dagger$ & - & - & 405 \\
\hline 11 & + & - & - & - & - & 205 \\
\hline 12 & + & $1 \cdot 31 \times 10^{5}$ & $1.88 \times 10^{4} \dagger$ & - & - & 398 \\
\hline 13 & + & $1.31 \times 10^{5}$ & $2.95 \times 10^{4 *}$ & - & - & 293 \\
\hline 14 & + & $1.02 \times 10^{7}$ & $1.97 \times 10^{4 *}$ & - & $3+$ & 370 \\
\hline 15 & + & $1.31 \times 10^{5}$ & $6.26 \times 10^{5 *}$ & - & - & 316 \\
\hline 18 & - & - & $1.64 \times 10^{5} \dagger$ & - & - & 409 \\
\hline 19 & + & - & - & - & - & 432 \\
\hline 21 & - & - & $9.48 \times 10^{4} *$ & $\begin{array}{c}+(\mathrm{LJ} \ddagger) \\
\text { M. gordonae }\end{array}$ & $3+$ & 396 \\
\hline 22 & + & - & - & - & - & 307 \\
\hline 23 & + & - & - & - & - & 270 \\
\hline 25 & + & $9 \cdot 24 \times 10^{9}$ & $4.59 \times 10^{4 *}$ & - & $6+$ & $\begin{array}{c}1160 \\
\text { (positive) }\end{array}$ \\
\hline 26 & - & - & - & - & $1+$ & 240 \\
\hline 27 & + & - & - & - & - & 323 \\
\hline 28 & + & - & $3.08 \times 10^{5 *}$ & - & - & 235 \\
\hline 29 & - & - & $1.31 \times 10^{4 *}$ & $\begin{array}{c}+ \\
(\mathrm{LJ} \& 7 \mathrm{H} 11 \ddagger) \\
\text { M.scro. }\end{array}$ & $4+$ & $\begin{array}{c}603 \\
\text { (equivocal) }\end{array}$ \\
\hline 30 & + & $2.00 \times 10^{9}$ & $3 \cdot 14 \times 10^{5 *}$ & - & $5+$ & $\begin{array}{c}907 \\
\text { (positive) }\end{array}$ \\
\hline $\begin{array}{c}\text { Total } \\
\text { number }\end{array}$ & 16 & 8 & 12 & 2 & 9 & \\
\hline
\end{tabular}


precautions was studied using 5 different methods, namely (a) PCR; (b) examination of direct smear; (c) mouse footpad study; (d) culture in laboratory media; and (e) histopathology. AFB were discovered in 21 of the 30 specimens studied $(70 \%)$ (Table 1$)$.

\section{PCR STUdies (Table 1)}

Detection of the $M$. leprae-specific $360 \mathrm{bp}$ fragment by PCR indicating the presence of $M$. leprae were obtained in 16 specimens $(53 \cdot 3 \%)$. In 5 among them, only PCR signals were positive for $M$. leprae and all other tests were negative. There were 5 which were AFB positive according to one or more of the other methods, but were PCR negative. Samples testing negative by PCR, but containing noncultivable AFB were spiked with $1 \mathrm{pg}$ of $M$. leprae DNA and retested by PCR. All samples spiked with $M$. leprae DNA in this manner tested positive for the $360 \mathrm{bp}$ PCR product indicating the samples were not inherently inhibiting in the PCR test. Of the 16 positive specimens, 8 were positive by both agarose gel electrophoresis and hybridization (Nos 3, 10, 12, 13, 14, 15, 25 and 30) while the other specimens were positive by hybridization only:

\section{MICROBIOLOGICAL STUDIES}

Smear from homogenates of lymph nodes (Table 1)

Direct smear from homogenates of lymph nodes from 8 animals showed AFB. Except one (No. 1), all recorded positive PCR signals and were found to grow in footpads of mice.

\section{Mouse foot pad studies (Table 1)}

From 12 specimens growth was registered in the footpads of mice. Nine of them had positive PCR signals and 2 were culturable in laboratory media. In one, all other tests to identify the presence of mycobacteria were negative (No. 18).

\section{Culture in laboratory media ( $L J \& 7 H 11$ )}

The homogenate from the lymph node was cultured in both $\mathrm{LJ}$ and $7 \mathrm{H} 11$ media at $25^{\circ} \mathrm{C}$, $33^{\circ} \mathrm{C}$, and $37^{\circ} \mathrm{C}$. From 2 specimens (Nos 21 and 29) AFB were grown at $37^{\circ} \mathrm{C}$ in $\mathrm{LJ}$ medium and from one (No. 29), in both LJ and $7 \mathrm{H} 11$ media at $37^{\circ} \mathrm{C}$. No growth was detected at $25^{\circ} \mathrm{C}$ and $33^{\circ} \mathrm{C}$ with either medium up to 8 weeks. Both positive specimens had negative PCR signals. However, both registered growth in the footpads of mice and were present in histopathology sections stained for AFB. They were identified as M. gordonae (No. 21) and M. scrofulaceum (No. 29). The organisms obtained from the mouse footpads were also subjected to PCR tests for $M$. leprae and were found negative. They were again identified as $M$. gordonae and $M$. scrofulaceum according to standard identification procedures. $^{13}$

\section{HISTOPATHOLOGICAL STUDIES}

\section{The right inguinal node (Table 1)}

Histopathological examination of the right inguinal lymph node showed marked reticuloendothelial hyperplasia and prominent germinal centres. The sinusoids in some lymph nodes were packed with large collections of macrophages and occasional 
neutrophils. There were small and large clumps of mast cells distributed irregularly both in the cortex and in the medulla. There were no granulomas or any identifiable difference in the lymph nodes of 7 animals which showed AFB up to $3+$ load (1 to 10 bacilli per oil immersion field). However, in one animal there were a few focal areas of epithelioid cells with poorly formed giant cells, and the granuloma lacked organization. Only 2 animals (Nos 25 and 30) showed macrophages characteristic of lepromatous disease with abundant pink granular cytoplasm replacing large areas of normal lymph node tissue. Foamy degeneration, though present, was scarce. In the 2 animals (Nos 21 and 29) infected with $M$. gordonae and $M$. scrofulaceum there was no evidence of granuloma.

Acid-fast stain showed intracellular AFB mainly in the macrophages infiltrating the subcapsular region, and the sinusoids of lymph nodes of animals with less than $3+$ load. In 2 specimens (Nos 21 and 29) AFB were confined to certain localized spots and large areas of the lymph nodes did not show any bacilli. However, in animals with large loads of AFB (Nos 25 and 30) there was diffuse infiltration of the lymph nodes with AFB packed macrophages. Some of the mast cells also contained AFB. Morphologically atypical AFB not identifiable as $M$. leprae were seen in 3 animals (Nos 1, 21 and 29) in the right inguinal node (Table 1). Two of these were grown in laboratory media and mouse footpads (Nos 21 and 29). In one the mouse footpad inoculation test was not done, and it did not grow in laboratory media.

\section{HISTOPATHOLOGY OF OTHER ORGANS}

\section{Changes in organs with $A F B$ (Table 2)}

AFB were present in one or more tissues in 14 of the 30 armadillos. Four of these animals (Nos 3, 14, 25 and 30) had lepromatous granulomas in the liver, spleen, axillary and inguinal nodes as evidence of disseminated leprosy. One or more footpads were also infiltrated with lepromatous granulomas. The nose was infected in 3 , the sciatic nerve in 2 , the tongue in 2 , the ears and other organs in only one with advanced disease. Skin nodules were present in 3 of them. The lepromatous granulomas in all organs were composed of mostly macrophages with clumps of intracellular AFB. In one animal (No. 3), there was a single large skin nodule measuring $2.0 \mathrm{~cm}$ in diameter in the left inguinal region and histologically it consisted of a large collection of bacilli-filled macrophages and scattered lymphocytes. There were also a few areas of necrosis.

Where the bacillary load was less than $3+$ the presence of AFB did not evoke any specially identifiable cellular reaction.

AFB associated with thorns were seen in the footpads of 5 animals and in the noses of 3 animals. AFB were found only in association with a thorn in the nose of one animal (No. 11) and in the left hind footpad of another animal (No. 19).

\section{Other lesions}

Of the 30 animals autopsied 15 showed thorns in all 4 feet, and 14 more had thorns in at least one foot. Thorns were present in the noses of 9 and in the ears of 14 armadillos. The thorns were invariably surrounded by a foreign body granulomas. Occasionally they were enveloped in dense hyalinized fibrous tissue. Sarcocystis was present in the tongue muscles in 22 animals and in the cardiac muscle in one and the striated muscles of the foot 
Table 2. Armadillos (13) with histopathological evidence of AFB

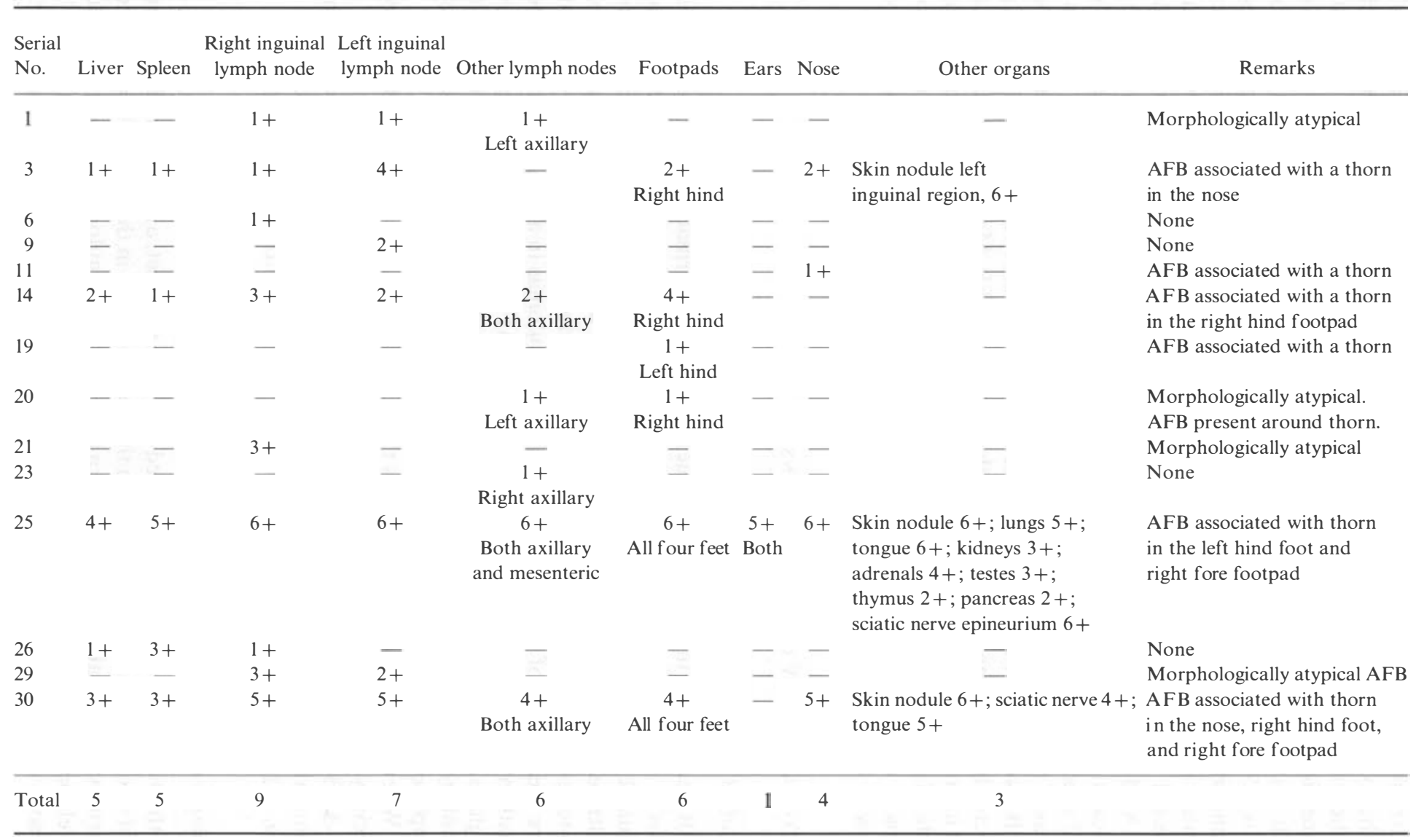


Table 3. Armadillos (9) with all 5 tests negative for $\mathrm{AFB}$ in the right inguinal lymph node and IgM antibodies to PGL-1 ELISA absorbance OD $\times 10^{3}$

\begin{tabular}{cc}
\hline & $\begin{array}{c}\text { IgM antibodies to PGL-1 ELISA } \\
\text { absorbances }\left(\text { OD } \times 10^{3} \text { ) }\right.\end{array}$ \\
\hline 2 & 654 \\
4 & (equivocal) \\
7 & 482 \\
8 & 579 \\
& 585 \\
9 & (equivocal) \\
16 & 403 \\
& 730 \\
17 & (false positive) \\
20 & 306 \\
& 381 \\
\hline
\end{tabular}

in one. Fragments of adult schistosomes with granulomatous reaction around them were found in liver, lung, and lymph nodes in the axillae, inguinal region and the mesentery in 19 animals.

\section{IgM antibodies to PGL-1(Tables 1 and 3)}

The values were positive in 3 animals (Nos 16, 25 and 30). Two of them (Nos 25 and 30) had disseminated disease with high bacterial load in many organs. One animal with a positive value did not show evidence of AFB in any of the other tests. The ELISA absorbances of 2 of the animals (Nos 25 and 30) were significantly reduced when their plasmas were adsorbed with whole $M$. leprae. Absorbances were not altered when they are adsorbed with other mycobacterial antigens. The ELISA absorbance of animal 16 was significantly reduced when its plasma was adsorbed with both $M$. leprae and $M$. kansasii and, therefore, was considered false positive.

\section{Discussion}

Using direct smear, laboratory culture, mouse footpad studies, histopathological examination and PCR techniques, AFB were found in the right inguinal lymph nodes of 21 of the 30 wild nine-banded armadillos investigated (70)\% (Table 1). Of these, 16 animals $(53 \cdot 3 \%)$ had positive PCR for $M$. leprae. Experimental studies have shown that the PCR method used in this investigation is highly specific for M. leprae. ${ }^{10}$ Therefore, it is reasonable to conclude that $53 \cdot 3 \%$ of the armadillos were infected with $M$. leprae. Of the other 5 animals with AFB in their right inguinal nodes, 2 had culturable AFB using Lowenstein-Jensen and 7H11 media. The AFB in the other 3 may by the highly fastidious, armadillo-derived mycobacteria (ADM). ${ }^{15,16}$ 
There is much interest in the study of the effects of previous exposure of humans to environmental and pathogenic mycobacteria on susceptibility to $M$. leprae infection. ${ }^{17,18}$ No other associated mycobacteria were isolated from any of the 16 animals which had M. leprae infection by PCR, although 5 from the other 14 animals had evidence of another mycobacterial infection.

IgM antibodies to PGL-1 were detected in 2 of the 30 animals $(6 \cdot 7 \%)$. Both had advanced disseminated lepromatous disease with high bacterial loads. With the present cut-off values, the screening test for IgM antibodies to PGL-1 was not sensitive enough to detect early disease. Nevertheless, the test is highly specific and virtually always positive in lepromatous leprosy with high bacterial load. This finding is in keeping with our earlier reports. ${ }^{11,19}$

During histopathologic examination, although AFB were seen in different organs in 14 animals, only $4(13.3 \%)$ had macrophage granulomas characteristic of lepromatous leprosy as described in earlier studies. ${ }^{20-22}$ If the histopathological study was limited to the inguinal lymph nodes only 2 armadillos $(6 \cdot 7 \%)$ could be diagnosed as lepromatous animals. Biopsy study of ears in armadillos is considered a very useful, reliable and feasible method of detecting lepromatous disease. Only one animal $(3 \cdot 3 \%)$ showed lepromatous granuloma in the ears (Figure 1). When the bacterial load was less than $3+$ there was no specific tissue reaction to the presence of AFB. Until the disease was well established, it appeared to be a 'quiet invasion' by $M$. leprae.

Of the 4 animals which had acquired histologically identifiable lepromatous disease, 2 had such advanced lesions in many organs that it was not possible to trace the route of entry or the mode of spread of the disease. In the other 2 the disease was sufficiently early to derive some conclusions. In armadillo No. 3 there was a large single skin nodule in the left inguinal region composed of largely macrophages with a bacterial load of $6+$. The left inguinal nodes were infiltrated with macrophages having a bacterial load of $4+$. In the liver, spleen, and the right inguinal nodes there was a bacterial load of $1+$. It is highly likely that the skin nodule was the primary lesion following a local entry of $M$. leprae. Then there was a lymphatic spread to inguinal nodes followed by bacteraemia and dissemination of $M$. leprae to other sites. In animal 14, it seems reasonable to state that the organisms entered the right hind footpad, produced locally an extensive lepromatous granuloma with a bacterial load of $4+$ followed by a lymphatic spread to the regional

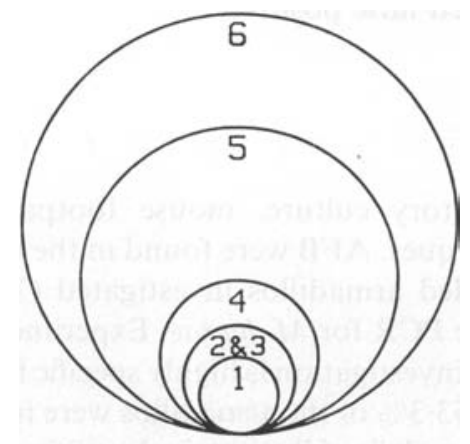

Figure 1. Comparison of PCR with other methods to detect Mycobacterium leprae. 1, Ear biopsy; 2, inguinal node biopsy; 3, IgM antibodies to PGL-1; 4, autopsy; 5, PCR study of inguinal lymph nodes; 6 , total number of animals examined (30). 
lymph nodes with a bacterial load of $3+$ and later a bacteraemic spread to other organs of the reticuloendothelial system. The nature of the initial lesion and the pattern of spread of the disease in these 2 animals were very similar to what was found in intracutaneously infected experimental armadillos. ${ }^{11}$

There is sufficient evidence in this study to infer that at least in a few animals $M$. leprae entered the body through the skin. Penetrating injuries by thorns had been associated with entry of $M$. leprae into the skin. ${ }^{23}$ In the present investigation one or more thorns were found in the footpad of all but one of the 30 armadillos studied. In 7 instances the thorns were associated with AFB in the tissues. In animal No. 11, AFB were present only in the nose, in animal No. 19 only in the left hind footpad, and in both armadillos the organisms were present in associations with thorns. Therefore, thorn pricks as a mode of entry of $M$. leprae into the skin of the armadillos is a clear possibility, if not probability.

In this study, 16 of the wild armadillos had evidence of infection with $M$. leprae in their right inguinal nodes. In an earlier report when armadillos were experimentally-infected subcutaneously in the footpads with $M$. leprae, 17 of the 18 showed $M$. leprae in the regional lymph nodes but only 10 had lesions at the site of inoculation. The lower the dose of infection the less likely it was to have a local lesion at the site of entry. ${ }^{11}$ A thorough microbiological and pathological study including PCR for $M$. leprae of superficial lymph nodes of normal contacts of leprosy patients with a high level of IgM antibodies to PGL-1 may yield very valuable data and add to our understanding of the pathogenesis of leprosy.

In 5 of the PCR positive animals there was no evidence of $M$. leprae in any of the other tests including histopathological examination. In patients with indeterminate leprosy, with polar tuberculoid disease and with lesions highly suspicious of leprosy, detection of $M$. leprae in biopsies can be crucial in confirming the diagnosis. Search for M. leprae in histopathologic sections is often unproductive. The use of PCR as a specific and sensitive tool to detect $M$. leprae in such cases should be further investigated.

Two animals as mentioned earlier had cultivable mycobacteria and they were identified as M. gordonae and M. scrofulaceum. AFB found in these animals grew in the footpads of mice. The footpad isolates were further tested and were found to be M. lepraePCR negative and were again identified as $M$. gordonae and $M$. scrofulaceum using standard identification procedures. ${ }^{13}$ It is possible to obtain multiplication in mouse footpads which is similar to that of $M$. leprae with other mycobacteria also.

\section{Acknowledgment}

We are grateful to the American Leprosy Mission, Inc., for funding this study and to Ms Rosie Hauge for secretarial assistance.

\section{References}

1 Walsh GP, Storrs EE, Burchfield HP, Cottrell EH, Vidrine MF, Binford CH. Leprosy-like disease occurring naturally in armadillos. J Reticuloendothel Soc, 1975; 18: 347-51.

2 Walsh GP, Storrs EE, Meyers WM, Binford CH. Naturally acquired leprosy-like disease in the nine-banded armadillo. Recent Epizootiological Findings. J Reticuloendothel Soc, 1977; 22: 363-7.

3 Smith JH, File SK, Nagy BA, Folse DS, Buckner JA, Webb LJ, Beverding AM. Leprosy-like disease of wild armadillos in French Acadiana, Louisiana. J Reticuloendothel Soc, 1978; 24: 705-14. 
${ }^{4}$ Smith JH, Folse DS, Long EG, Christie JD, Crouse DT, Tewes ME, Gatson AM, Ehrhardt RL, File SK, Kelly MT. Leprosy in wild armadillos of the Texas Gulf Coast. Epidemiology and mycobacteriology. J Reticuloendothel Soc, 1983; 34: 75-88.

${ }^{5}$ Folse DS, Smith JH. Leprosy in wild armadillos on Texas Gulf Coast. Anatomic pathology. J Reticuloendothel Soc, 1983; 34: 341-57.

${ }^{6}$ Hunter SW, Brennan PJ. A novel phenolic glycolipid from $M$. leprae possibly involved in immunogenicity and pathogenicity. $J$ Bacteriol 1981; 147: 728-35.

7 Buchanan TM, Dissanayake S, Young DB, et al. Evaluation of the significance of antibodies to PGL-1 of $M$. leprae in leprosy patients and their contacts. Int J Lepr, 1983; 51: 658-9.

${ }^{8}$ Douglas JT, Celona RV, Abalos RM, Madarang MG, Fajardo T. Serological activity and early detection of leprosy among contacts of lepromatous patients in Cebu, The Philippines. Letter to the Editor. Int J Lepr, 1987; 55: 718-21.

9 Truman RW, Shannon EJ, Hagstad HV, Hugh-Jones ME, Wolff A, Hastings RC. Evaluation of the origin of M. leprae infections in the wild armadillo. Am J Trop Med Hyg, 1986; 35: 588-93.

${ }_{10}$ Williams DL, Gillis TP, Booth RJ, Looker D, Watson JD. The use of a specific DNA probe and polymerase chain reaction for the detection of M. leprae. J Infect Dis, 1990; 162: 193-200.

11 Job CK, Drain V, Truman RW, Deming AT, Sanchez RM, Hastings RC. The pathogenesis of leprosy in the nine-banded armadillo and the significance of IgM antibodies to PGL-1. Submitted for publication.

12 Ridley DS, Hilson GRF. A logarithmic index of bacilli in biopsies. Int J Lepr, 1967; 35: 184-6.

13 Vestal AL. Procedures for the isolation and identification of mycobacteria. U.S. Department of Health, Education, and Welfare: Centers for Disease Control. Atlanta, GA. 1977.

14 Shepard CC, McRae DH. A method for counting acid-fast bacteria. Int J Lepr, 1968; 36: 78-82.

15 Dhople AM, Kazda J, Green KJ, Storrs EE. Presence of difficult to isolate mycobacteria in armadillos. Ind J Lepr, 1986; 58: 29-37.

16 Portael F, DeRidder K, Pattyn SR. Cultivable mycobacteria isolated form organs of armadillos uninoculated and inoculated with M. leprae. Ann Inst Pasteur Microbiol, 1985; 136: 181-90.

17 Stanford JL, Shield MJ, Rook GA. How environmental mycobacteria may predetermine the protective efficacy of BCG. Tubercle, 1981; 62: 55-62.

18 Rook GA, Bahr GM, Stanford JL. The effect of 2 distinct forms of cell mediated response to mycobacteria on protective efficacy of BCG. Tubercle, 1981; 62: 63-8.

19 Vaidee AR, Shannon EJ, Gillis TP, Mshana RN, Hastings RC. Armadillo IgG and IgM antibody responses to PGL-1 during experimental infection with M. leprae. Int J Lepr, 1988; 57: 422-7.

20 Job CK, Sanchez RM, Hastings RC. Manifestations of experimental leprosy in the armadillo. Am J Trop Med Hyg, 1985; 34: 151-61.

${ }^{21}$ Binford $\mathrm{CH}$, Storrs EE, Walsh GP. Disseminated infection in the nine-banded armadillo resulting from inoculation with M. leprae. Int J Lepr, 1976; 44: 80-3.

${ }^{22}$ Meyers WM, Walsh GP, Binford CH, Storrs EE, Brown HL. Indigenous leprosy in nine-banded armadillos. The armadillo as an experimental model in biomedical research. Pan American Health Organization Scientific Publication No. 366. 1978; 67-76.

23 Job CK, Harris EB, Allen JL, Hastings RC. Thorns in armadillo ears and noses and their role in the transmission of leprosy. Arch Path Lab Med, 1986; 110: 1025-8. 


\title{
Comparaison de la methode de la polymerase chain reaction avec celle du depistage du Mycobacterium leprae chez 30 tatous chez qui un marquage en bandes sequentielles du chromosome 9 à été effectué
}

\author{
C K Job, V Drain, D L Williams, T P Gillis, R W Truman, R M Sanchez, \\ A T Deming ET R C Hastings
}

\begin{abstract}
Résumé Trente tatous furent choisis au hasard dont le chromosome 9 avait été marqué en bandes séquentiel les, pesant entre 3 et 5 kilos et pris au piège dans une région où la lèpre des tatous est endémique; ils furent tués, une autopsie fut faite ainsi qu'un examen histopathologique. Un des ganglions inguinaux droits fut également enlevé dans des conditions stériles et examiné par la méthode de la polymérase chain reaction, du frottis direct, par l'étude de sensibilité sur le coussinet plantaire de la souris, par culture dans un milieu de laboratoire et par examen histopathologique afin de dépister le Mycobacterium leprae. Le sang fut prélevé à la mort et examiné pour déterminer les anticorps IgM dirigés contre PGL-1.

D'après l'étude de polymérase chain reaction des ganglions inguinaux, des preuves de $M$. leprae existaient chez 16 des 30 tatous $(53,3 \%)$. Des taux importants d'anticorps IgM dirigés contre PGL-1 et des granulomes lépromateux identifiables dans les ganglions inguinaux furent trouvés chez 2 animaux $(6,7 \%)$ présentant un stade avancé de dissémination de la maladie. D'après l'autopsie, la prévalence de la lèpre généralisée était de $13,3 \%$ et d'après l'examen histopathologique des tissues de l'oreille de 3,3\%. La présence de $M$. leprae dans les tissues ne donna lieu à aucune réaction tissulaire spéciale aux premiers stages. Le schéma de la propagation de la maladie chez 2 animaux resemblait fort à celui des animaux expérimentaux infectés intracutanément. Il est très probable que l'infection par inoculation de $M$. leprae avait été causée par des piqûres d'épines.
\end{abstract}

\section{Comparacion de la tecnica de reaccion en cadena por polimerasa con otros metodos de deteccion de Mycobacterium leprae en los tejidos de armadillos salvajes, de nueve bandas}

\author{
C K Job, V Drain, D L Williams, T P Gillis, R W Truman, R M Sanchez, \\ A T DEMING Y R C HaSTINGS
}

Resumen Se atraparon al azar treinta armadillos de nueve bandas, con pesos entre 3 y 5 kilogramos, en una zona que era endémica para la lepra en armadillos; después de matarlos, y realizar una autopsia, se les hizo un estudio histopatológico. Además, se hizo una extracción de los nodos linfáticos inguinales derechos tomando precauciones de esterilidad, y se les examinó utilizando PCR, estudio director de frote, examen de pata de ratón, cultivo en medios de laboratorio e histopatología con la intención de detectar Mycobacterium leprae. Se recogió sangre al momento de muerte y se hicieron pruebas para anticuerpos IgM según PGL-1.

Según el estudio PCR (Reacción en Cadena por Polimerasa) de los nodos linfáticos inguinales, 16 de los 30 armadillos $(53,3 \%)$ indicaban la presencia de $M$. leprae. Se encontraron niveles significativos de anticuerpos IgM según PGL-1, y en 2 animales (6,7\%), se encontraron granulomas lepromatosas identificables con un estada avanzado de enfermedad diseminada. Según el estudio por autopsia, la presencia generalizada de lepra era un $13,3 \%$, y según un examen histo-patológico del tejido del oído un 3,3\%. La presencia de $M$. leprae en los tejidos no provocó una reacción tisular especial en las primeras etapas. La forma en que se diseminó la enfermedad en los animales se parecía mucho a la que se encuentra en los animales de laboratorio infectados por vía intracutánea. Es muy posible que la iniciación de la infección por inoculación de $M$. leprae resulte de pinchazos causados por espinas. 